\title{
Tracer study as an effort to improve higher islamic education quality and relevance
}

\author{
Uswatun Khasanah \\ Institut Agama Islam Negeri (IAIN) Pekalongan \\ uswatun.khasanah@iainpekalongan.ac.id
}

DOI: 10.18326/attarbiyah.v4i2.121-143

\begin{abstract}
This study identifies the profile of alumni and determines their absorption in the employment; describe their assessment of the organization and quality of services; and describes user ratings of alumni performance. This research includes a qualitative descriptive through a survey approach which includes stages: the development of concepts and instruments; data collection; data analysis and reporting. The subjects of this study were alumni of FUAD IAIN Pekalongan (graduated in 2013-2016). The number of respondents was 88 alumni and 14 alumni users. Primary data were obtained through an online structured questionnaire through Google forms, POS and direct dissemination. Data collection was conducted in May-August 2018. The results are: (1) Alumni profiles have high absorption, i.e. $47 \%$ of respondents in working positions, $21 \%$ of entrepreneurs, $16 \%$ of workers and entrepreneurs and $16 \%$ of not working/continuing their studies; (2) Alumni assessment of the organization and quality of services is "good", but there is still a need to improve aspects of facilities and infrastructure; (3) Alumni users judge the performance of alumni in the "good" category. The alumni competence in terms of aspects of integrity; professionalism; use of information technology, communication; teamwork; and self-development is "good".
\end{abstract}

Keywords: survey research, tracer study, alumni, higher Islamic education 
Attarbiyah: Journal of Islamic Culture and Education

https://www.attarbiyah.iainsalatiga.ac.id/index.php/attarbiyah/

\section{INTRODUCTION}

Alumni have a very strategic role in improving the performance and quality of their almamater. Establishing a strong relationship between alumni and alma mater is one factor in improving the quality of higher education. The quality of a tertiary institution can be seen from the 'final product' of the tertiary institution, namely alumni. This is very relevant, because the success of alumni in social life greatly affects the reputation of higher education in the eyes of the community. Furthermore, Sukardi (2011: 197) stated that the activities of the alumni after passing through their education period and how they passed the transition from higher education to the world of work is one of the benchmarks of the success of higher education (Sukardi, 2011). The performance of alumni can be seen from the number of alumni who work in relevant fields, where they work, the way they get a job, the benefits of knowledge and skills obtained from tertiary institutions, career development in the world of work, positions held, and so forth. Therefore, knowing the alumni's perceptions regarding the educational process they have participated in is important to do. This is feedback from alumni that can at least be useful in helping universities make improvements to the system and management of education.

However, not many universities realize and then make strategic efforts that lead to the use of alumni for the development of tertiary institutions. To measure the success and quality of alumni, one of the important activities carried out is tracer study. This tracer study was conducted to gather information about alumni. The aim is to find out the results of the education

process that have been carried out, find out the competencies of alumni, the 
contribution of universities to mastery of these competencies, and to gather further information to the alumni as input for future improvement.

Based on the preliminary observations of researchers, very little research has been found that traces the track record of IAIN Pekalongan alumni, and there is no tracer study of alumni Faculty of Ushuluddin, Adab and Dakwah (FUAD) of IAIN Pekalongan. Thus, it can be said that there is almost no feedback from Alumni to improve the quality of education for the college itself. Tracer study is a bridge between research and the need for universities to develop into a necessity. Therefore, the author consider it important to do a tracer study of FUAD alumni at IAIN Pekalongan. The focus of the problem in this study are: 1) what is the profile of Alumni of FUAD IAIN Pekalongan and their absorption in employment?; 2) how is the assessment of alumni regarding the implementation and quality of services available in FUAD IAIN Pekalongan; and 3) how are the alumni user ratings on the performance of FUAD IAIN Pekalongan alumni?

The definition of alumni profile here includes 3 (three) things, namely the waiting period to get the first job, the field of work, and the first income obtained by the Alumni. Implementation and quality of service referred to herein is related to aspects of learning, aspects of teaching and learning, conditions of learning facilities, the contribution of tertiary institutions to competencies and foreign languages and the benefits of majors for alumni. Alumni user assessment here related to Alumni performance includes: integrity, expertise based on the field of science (professionalism), English, the use of information technology, communication, teamwork and selfdevelopment ability. 
The results of this tracer study are in the form of information data that can be used for evaluating and improving the quality of education guarantees, improving career services for alumni, as well as education information and marketing in tertiary institutions. This is as stated by (Schomburg, 2003). Thus, this tracing study will have benefits for several parties. For the Faculty, this tracer study will be useful : 1) as the main input material for conducting dialogues both internally and externally, especially for the preparation of vision and mission, and curriculum; 2) as input for improving the quality of credible, transparent and accountable governance; 3) to find out the level of relevance between the educational programs organized and the needs of the world of work; 4) to find out changes and the need for capabilities and capabilities in accordance with the conditions in the complex world of work through the opinions of alumni; 5) as information about various deficiencies that might occur in the education process and the learning process so that it can be the basis for planning activities for future improvement; 6) as material for building alumni networks. For Alumni, tracer study can be input to develop their capacity based on input from Alumni Users. Students will be able to open up greater employment opportunities when they have completed their studies.

Tracer study means an activity or study conducted to find out something by tracing or tracking. The object is alumni from tertiary institutions. Schomburg (2003) states that a survey of graduates from tertiary institutions or tracer studies is also called an alumni survey or a follow-up survey (Schomburg, 2003). Methodologically, tracer studies are used to analyze the relationship or suitability of college graduates with employment, which aims to complete data related to workforce, career, the relationship between 
work character and competence, as well as various information about the experience of graduates in the workplace.

Finch and Crunkilton (1979: 11) state that the purpose of tracer studies is to find out alumni mobility, how satisfied alumni are with their work, employers' views on alumni performance and more importantly, to find out how far educational programs have prepared alumni to develop further careers (Finch \& Crunkilton, 1979). Halasz and Behm (1982: 9) say that the purpose of tracer studies is for program planning, decision making, professional development, program improvement, accountability and accreditation (Halasz \& Behm, 1982). The implementation of tracer studies can also be used as a basis for future planning activities related to improving education services and programs. The importance of tracer study makes the need for information on career, status, income, relevance of knowledge and skills and the conditions of study of graduates is needed. Tracer study data is very important for the continued development and improvement of higher education institutions (Suryani, Khairudin, \& Syahmaidi, 2017).

Tracer study as mentioned in the Dikti Career Center Guidebook can be carried out between 1-3 years after students graduate. Within that timeframe, alumni are considered to have sufficient experience and competence in work as well as sufficient knowledge about the world of work (Ditjen Belmawa, 2016; Budi \& Dinan, 2017). In the ITB Tracer Study Report Book (2014: 14) it is mentioned that tracer studies can also be carried out for alumni 4-5 years after graduation but are only looking for information, identifying the development patterns of alumni work (ITB, 2014). However, if carried out for longer than 3 years after graduation, the tracer study conducted has weaknesses. If this study is conducted immediately after graduation, this 
study is called an exit study. But the exit study cannot optimally capture the entire work transition process because in a period that is too short after graduating, it is likely that the work situation has not been stable or there may even be graduates who have not found work.

The relevance of education, in the Accreditation Guide, is the level of relevance of objectives and program outputs in terms of the normative ideal size supported by the determination of input, process and output elements. Relevance of education which means there are a match in the form of link and match, in fact education is in accordance with the needs of the community. Education is always considered as the main element in the development of Human Resources (HR). HR will be seen as valuable if it has attitudes, behaviors, insights, abilities, expertise and skills that are appropriate to the needs of the community. Thus, the relevance of this education seems to always be related to the level of suitability of education with the work of alumni. This can be seen from the job profile, position/work load, salary level and courses that are useful/support the work of alumni in the world of work.

The relevance of higher education for students is related to alumni who will adjust to and participate in the world of work. The relevance of this education can be understood as a dynamic concept and multi-dimensional opportunity. As Soesilo \& Setyorini (2005) states three things, namely: (1) Relevance is a multidimensional cognitive concept whose meaning is largely dependent on uses' perceptions of information-need situations; (2) Relevance is a dynamic concept that depends on users' judgments of the quality of relationships between information and information-need at a certain point in time; and (3) Relevance is a concept if approached conceptually and operationally from a user's perspective (Soesilo \& Setyorini, 2005). 
Absorption of alumni by the world of work certainly depends on the quality of graduates formed by the integration of the skills, knowledge and competencies of the graduates. Quality, relevance and competence are the three aspects of higher education that are always interrelated with one another. The three also contributed directly to increasing the nation's competitiveness in the aspect of HR. Increasing the relevance of these tertiary institutions should always be a serious concern and be part of an overall university quality assurance system.

There are no studies that trace the track record of FUAD IAIN Pekalongan Alumni. A study on alumni of IAIN Pekalongan was conducted by Agus Arwani, et al (2015). The study focused on examining the contributions of alumni of Islamic Banking and Islamic Economics, not yet examining aspects of the curriculum and its relevance to the world of work (Arwani, 2015). This is certainly different from this study which will focus on examining the perceptions of FUAD alumni of the curriculum and its relevance to the world of work.

Nurchamid (2017), then, described the management of alumni at the STAIN Pekalongan level and explored all forms of contributions and roles that were given by the Tarbiyah STAIN Pekalongan alumni. He classified the role of alumni into 2 fields namely related to academic and non-academic fields. These contributions include the role of Alumni in updating the curriculum, continuing education and developing the customer satisfaction index (Nurchamid, 2017).

Tracer study studies that have been carried out include a research of Lieli Suharti (2012: 232). With a descriptive approach, this study obtained an overview of the alumni career which includes the waiting period of the first 
job, job position, suitability of the field of work with the field of study, and input from alumni for the future development of the study program curriculum (Suharti, 2012). The research has not explored Alumni User responses about Alumni performance as will be explored in this study.

Research focusing on studies on the development of a tracer study system was carried out by Komang Setemen (2009). The result is an alumni information system as an alumni database to find out the alumni absorption status in the business and industrial world (Setemen, 2009). This web-based system was developed so that it can be accessed by many people, and if there are improvements to the data related to the alumni themselves can be done by those concerned. Hermanto, et al. (2015) and Syam, et al (2017) also develop a Web-based tracer system. Assisted by the internet, the website-based system makes it easy for student staff and alumni to input anywhere (Hermanto, Furqan, \& Hasyim, 2015; Syam \& Manga, 2017).

While Eka Yani, et al., (2012) explored a study that describes: (1) graduate profile, (2) graduate learning experience, (3) quality of performance, competence and competitiveness of graduates, (4) graduate satisfaction with the learning system at the UT, (5) graduates' desire to further studies, (6) stakeholder assessments of graduates, and (7) graduate participation in the UT Alumni Association (Yani, Pertiwi, Fadila, Puspitasari, \& Huda, 2012). The data obtained were analyzed descriptively, and presented in the form of frequency and percentage tabulations.

Another study was conducted by Maryam Rahim (2017). With a quantitative analysis, this study produces data: 1) the average graduate waiting period is 3 months; 2) the type of work the graduates have taken on consists of 
13 categories; and 3) user responses to graduates on average respond well (Rahim, 2017).

\section{METHODS}

The research design used was cross sectional. This is because the data collection was carried out once to Alumni of FUAD IAIN Pekalongan graduated in 2013-2016. The stages of the research consisted of 3 stages, namely the development of concepts and instruments, data collection, and subsequent data analysis and report writing. The population as well as the subject of this research are Alumni of FUAD IAIN Pekalongan in 2013-2016 totaling 121 people. The respondents included 88 Alumni and 14 Alumni Users.

Data sources used in this study include primary and secondary data. Primary data were obtained directly from distributing questionnaires to Alumni and Alumni Users. While secondary data in the form of documentation Alumni data obtained from the Faculty. Data collection techniques in this study through questionnaires, interviews and documentation. The questionnaire used here adopted the Bandung Institute of Technology's tracer study questionnaire. Interviews were conducted to Alumni Users face-to-face and via telephone to obtain further information related to Alumni performance. The documentation method is used to supplement data not obtained with the two previous techniques, in the form of alumni identity documents for graduates of 2013-2016, graduation albums and FUAD IAIN Pekalongan profiles. All data collected was analyzed using descriptive percentage analysis techniques. 
Attarbiyah: Journal of Islamic Culture and Education

https://www.attarbiyah.iainsalatiga.ac.id/index.php/attarbiyah/

\section{DISCUSSION}

Tracer studies are carried out by sending questionnaires both online and offline. Filling out the questionnaire online is carried out by sending a questionnaire via Whatsapp Chat, email, telephone. The offline questionnaire filling was carried out by sending questionnaires to alumni and alumni users through POS services and sending directly to the respondent's address by the surveyor team.

After verification by the surveyor team, the tracer study involved 120 people, 1 alumnus was not involved because he had died, but only 107 alumni had validated addresses and telephone numbers. Tracer study of FUAD IAIN Pekalongan alumni carried out for 3 months, from mid-May 2018 until the end of August 2018. During these 3 months, researchers obtained a response rate of $73 \%$. These 88 alumni are referred to as actual participants/responses. The remaining 32 people did not fill in because: 1) 19 alumni did not give a positive response, even though they had been contacted several times and sent questionnaires via POS, 2) 13 alumni without information, meaning, the questionnaire had been sent to the home address, but not there is a response. Thus, the Gross Response Rate of the Pekalongan FUAD IAIN alumni tracer study was $73 \%$.

The tracer study results are presented as follows:

1. The highest FUAD alumni grade point average (GPA) is 3.97 and the lowest is 2.19 .

2. $72 \%$ of FUAD alumni during college live with parents, $5 \%$ share a boarding house/apartment/rent house, $8 \%$ live in their own house, $7 \%$ live in Islamic boarding schools, $4 \%$ live alone in boarding houses, $2 \%$ live 
together Foster Parents, 1\% become mosque ta'mir and 1\% live with relatives.

3. $49 \%$ of FUAD alumni receive tuition fees from parents or family, $32 \%$ come from scholarships, $10 \%$ come from their own expenses, $7 \%$ come from scholarships, $1 \%$ comes from foster parents, and the other $1 \%$ comes from work.

4. $83 \%$ of FUAD alumni were actively involved in the organization during the study period and the remaining $17 \%$ were not involved in organizational activities. The level of activity was $8 \%$ classified as very active, $42 \%$ active, $38 \%$ were quite active, $11 \%$ were less active and $1 \%$ was passive.

5. $60 \%$ of FUAD alumni undertook their studies for approximately 4 years, $32 \%$ for 5 years, $6 \%$ for 6 years and $2 \%$ for 3 years.

6. $12 \%$ of FUAD alumni get their first job before graduation and $88 \%$ after graduation. $83 \%$ of $88 \%$ of alumni who find jobs after graduation wait for less than one year and 5\% wait for more than one year.

7. As many as $47 \%$ of FUAD alumni in working positions, $21 \%$ in entrepreneurship. While alumni who work as well as entrepreneurs by $16 \%$ and alumni who do not work/continue their studies by $16 \%$.

8. The fields of work carried out by FUAD alumni are economic 5\%, social $7 \%$, tourism $2 \%$, agriculture and animal husbandry $2 \%$, information and communication 5\%, industry and processing 12\%, dakwah $18 \%$, administration 5\% and education 44\%.

9. $65 \%$ of FUAD alumni received the first salary of $<\mathrm{Rp}$. 1,000,000; of which 5\% received between Rp. 1,000,000 to Rp. 3,000,000; and 30\% of alumni do not answer questions about salaries. 
10. As for the current salary (during the questionnaire filling period); $41 \%$ of FUAD alumni received the first salary of $<\mathrm{Rp} .1,000,000 ; 37 \%$ received between Rp. 1,000,000 to Rp. 3,000,000; 7\% received between Rp. 3,000,000- Rp. 5,000,000; and 15\% of alumni do not answer questions about salaries.

11. FUAD alumni assessments for learning aspects are shown in Table 1.

\begin{tabular}{lccccc}
\hline \multirow{2}{*}{ Learning Aspects } & \multicolumn{5}{c}{ FUAD Alumni Assessments } \\
\cline { 2 - 6 } & Poor & Fair & Good & Very Good & Excellent \\
\hline Lecture/ Learning & 0 & 1 & 6 & 43 & 38 \\
\hline $\begin{array}{l}\text { Demonstration/ } \\
\text { Experiment }\end{array}$ & 3 & 4 & 23 & 43 & 15 \\
\hline $\begin{array}{l}\text { Participation in } \\
\text { research projects }\end{array}$ & 3 & 2 & 23 & 39 & 21 \\
\hline An internship & 3 & 1 & 15 & 49 & 20 \\
\hline Field practice & 0 & 3 & 10 & 46 & 29 \\
\hline Discussion & 0 & 0 & 11 & 40 & 37 \\
\hline
\end{tabular}

Table 1. FUAD Alumni Assessments for Learning Aspects

12. FUAD alumni assessments for aspects of teaching and learning are shown by Table 2 .

\begin{tabular}{|c|c|c|c|c|}
\hline \multirow[b]{2}{*}{ Aspects of Teaching and Learning } & \multicolumn{4}{|c|}{ FUAD Alumni Assessments } \\
\hline & Poor & Fair & Good & $\begin{array}{l}\text { Very } \\
\text { Good }\end{array}$ \\
\hline $\begin{array}{l}\text { The opportunity to interact with lecturer } \\
\text { outside the class schedule }\end{array}$ & 3 & 7 & 55 & 23 \\
\hline Academic guidance & 1 & 11 & 56 & 20 \\
\hline $\begin{array}{l}\text { The opportunity to participate in a resea1 } \\
\text { project }\end{array}$ & 3 & 25 & 46 & 14 \\
\hline General conditions of teaching and learn & 1 & 8 & 62 & 17 \\
\hline $\begin{array}{l}\text { The opportunity to enter and become pa } \\
\text { a network of professional scientists }\end{array}$ & 5 & 19 & 47 & 17 \\
\hline
\end{tabular}

Table 2. FUAD Alumni Assessments for Aspects of Teaching and Learning 
13. FUAD alumni assessments for learning facilities are shown in Table 3.

\begin{tabular}{lcccc}
\hline \multirow{2}{*}{ Aspects of Learning Facilities } & \multicolumn{5}{c}{ FUAD Alumni Assessments } \\
\cline { 2 - 5 } & Poor & Fair & Good & $\begin{array}{c}\text { Very } \\
\text { Good }\end{array}$ \\
\hline Library & 5 & 6 & 46 & 31 \\
\hline $\begin{array}{l}\text { Information and Communication } \\
\text { Technology }\end{array}$ & 4 & 9 & 56 & 19 \\
\hline Learning Module & 3 & 17 & 51 & 17 \\
\hline Study Room & 4 & 7 & 56 & 21 \\
\hline Laboratory & 7 & 16 & 53 & 12 \\
\hline Variety of courses offered & 1 & 15 & 55 & 17 \\
\hline Accommodation & 4 & 20 & 55 & 9 \\
\hline Canteen & 7 & 26 & 46 & 9 \\
\hline The center of student activities and facili. & 5 & 20 & 53 & 10 \\
\hline Mosque & 3 & 18 & 54 & 13 \\
\hline Health services & 8 & 16 & 57 & 7 \\
\hline & & & &
\end{tabular}

Table 3. FUAD Alumni Assessments for Learning Facilities

14. FUAD alumni assessment for the contribution of tertiary institutions to several competencies is shown in Table 4.

\begin{tabular}{|c|c|c|c|c|c|}
\hline \multirow{2}{*}{$\begin{array}{l}\text { The Contribution Of Tertiary } \\
\text { Institutions To Several } \\
\text { Competencies }\end{array}$} & \multicolumn{5}{|c|}{ FUAD Alumni Assessments } \\
\hline & Poor & Fair & Good & $\begin{array}{c}\text { Very } \\
\text { Good }\end{array}$ & $\begin{array}{c}\text { Excelle } \\
\text { nt }\end{array}$ \\
\hline Knowledge in scientific disciplines & 0 & 1 & 13 & 45 & 29 \\
\hline Knowledge outside of scientific discip & 0 & 3 & 23 & 48 & 14 \\
\hline General knowledge & 0 & 3 & 23 & 49 & 13 \\
\hline Internet skills & 0 & 6 & 19 & 49 & 14 \\
\hline Computer skills & 1 & 6 & 15 & 53 & 13 \\
\hline Critical thinking & 0 & 1 & 17 & 42 & 28 \\
\hline Research skills & 0 & 4 & 21 & 50 & 13 \\
\hline Learning ability & 0 & 1 & 17 & 57 & 13 \\
\hline Communication skills & 0 & 1 & 13 & 52 & 22 \\
\hline Work under pressure & 1 & 4 & 24 & 49 & 10 \\
\hline Time management & 0 & 4 & 15 & 55 & 14 \\
\hline Work independently & 0 & 2 & 14 & 57 & 15 \\
\hline Work in teams & 0 & 3 & 12 & 53 & 20 \\
\hline The ability to solve problems & 0 & 1 & 17 & 54 & 16 \\
\hline Negotiation & 1 & 3 & 21 & 48 & 15 \\
\hline
\end{tabular}


Attarbiyah: Journal of Islamic Culture and Education

https://www.attarbiyah.iainsalatiga.ac.id/index.php/attarbiyah/

\begin{tabular}{|c|c|c|c|c|c|}
\hline Analytical skills & 0 & 1 & 21 & 49 & 17 \\
\hline Tolerance & 0 & 2 & 10 & 50 & 26 \\
\hline Adaptability & 1 & 2 & 10 & 53 & 26 \\
\hline Loyalty and integrity & 0 & 1 & 14 & 51 & 22 \\
\hline $\begin{array}{l}\text { Working with people from } \\
\text { different cultures and } \\
\text { backgrounds }\end{array}$ & 0 & 2 & 14 & 53 & 19 \\
\hline Leadership & 0 & 2 & 16 & 49 & 21 \\
\hline $\begin{array}{l}\text { The ability to hold } \\
\text { Responsibilities }\end{array}$ & 0 & 3 & 15 & 49 & 21 \\
\hline Initiative & 0 & 2 & 19 & 48 & 19 \\
\hline Project/ program management & 0 & 3 & 19 & 51 & 15 \\
\hline $\begin{array}{l}\text { The ability to present ideas/ products, } \\
\text { reports }\end{array}$ & 2 & 2 & 14 & 54 & 16 \\
\hline $\begin{array}{l}\text { Ability to write reports, memos } \\
\text { and documents }\end{array}$ & 0 & 5 & 15 & 53 & 15 \\
\hline $\begin{array}{l}\text { The ability to continue learning } \\
\text { throughout life }\end{array}$ & 0 & 2 & 15 & 36 & 35 \\
\hline
\end{tabular}

Table 4. FUAD Alumni Assessment for The Contribution of Tertiary Institutions to Several Competencies

15. FUAD alumni assessments for higher education contributions to foreign languages are 9\% (excellent), 45\% (very good), 35\% (good), 8\% (fair) and $3 \%$ (poor). The level of foreign language skills of alumni is $1 \%$ (very good), 43\% (good), 39\% (fair), and 17\% (poor).

16. FUAD alumni assessment for the benefits of the department in several cases is shown in Table 5 .

\begin{tabular}{lccc}
\hline \multirow{2}{*}{$\begin{array}{c}\text { The Benefits Of The Department In Several } \\
\text { Cases }\end{array}$} & \multicolumn{3}{c}{ FUAD Alumni } \\
& Assessments \\
\cline { 2 - 4 } & $\begin{array}{c}\text { Poor } \\
\text { Starting work }\end{array}$ & $\begin{array}{c}\text { Fair } \\
\text { Good }\end{array}$ \\
\hline Further learning at work & 5 & 32 & 52 \\
\hline Performance in carrying out tasks & 5 & 30 & 53 \\
\hline Future Career & 7 & 27 & 54 \\
\hline Self-development & 1 & 22 & 65 \\
\hline Improve entrepreneurial skills & 11 & 32 & 45 \\
\hline
\end{tabular}


Table 5. FUAD Alumni Assessment for The Benefits of The Department in Several Cases

17. Alumni user ratings for alumni performance on some abilities are shown in Table 6.

\begin{tabular}{lcccc}
\hline \multirow{2}{*}{$\begin{array}{c}\text { Alumni Performance On Some } \\
\text { Abilities }\end{array}$} & \multicolumn{4}{c}{ Alumni user Assessments } \\
\cline { 2 - 5 } & Poor & Fair & Good & $\begin{array}{c}\text { Very } \\
\text { Good }\end{array}$ \\
\hline Integrity & 0 & 7 & 64 & 29 \\
\hline Professionalism & 0 & 21 & 57 & 22 \\
\hline English Language Skill & 7 & 29 & 57 & 7 \\
\hline The use of information technology & 0 & 14 & 57 & 29 \\
\hline Communication skills & 0 & 14 & 50 & 36 \\
\hline Teamwork & 0 & 7 & 64 & 29 \\
\hline Self-development ability & 0 & 21 & 50 & 29 \\
\hline
\end{tabular}

Table 6. Alumni user ratings for alumni performance on some abilities

The profile of FUAD IAIN Pekalongan alumni can be seen from 3 (three) indicators namely the waiting period to get the first job, the percentage of graduates who have worked, and the first income obtained. Based on the research data mentioned earlier that $12 \%$ of respondents get their first job before graduation and the remaining $88 \%$ of respondents get their first job after graduation. The waiting period to get the first job of FUAD IAIN Pekalongan alumni is good, ie $12 \%$ of respondents get their first job before graduation, $5 \%$ of respondents get their first job more than 1 year of graduation and $83 \%$ of them wait less than 1 year of graduation.

The percentage of alumni who have worked as described in the previous section, that $47 \%$ of the number of respondents in working positions, $21 \%$ are entrepreneurs, $16 \%$ work and self-employed and $16 \%$ do not work/ continue their studies. The fields of work undertaken by FUAD IAIN Pekalongan alumni are very diverse, covering the fields of economy (5\%), Social (7\%), 
Tourism (2\%), Agriculture and Animal Husbandry (2\%), Information and Communication (5\%), Industry and Processing (12\%), Dakwah (18\%), Administration (5\%) and Education (44\%). Most of the jobs in Pekalongan FUAD IAIN alumni are in the field of education, followed by propaganda, even though this FUAD is not a faculty specializing in producing education personnel. It is possible that the field of work that is relatively easy to obtain for alumni is in the field of education. In other words, the teaching profession is still a favorite for alumni, especially FUAD IAIN Pekalongan alumni. When viewed from this aspect, it can be said that the alumni of FUAD IAIN Pekalongan are very easy to find jobs and easily absorbed by the community.

The first salary of alumni is a reflection of community appreciation for alumni competence, in this case is still relatively low, this is evident from the data that alumni who get salaries $<$ Rp. 1,000,000 (65\%); Rp. 1,000,000 to Rp. $3,000,000$ (5\%); while those who did not answer as much as 30\%. The current income received by alumni can be seen from the data that $<\mathrm{Rp} .1,000,000$ (41\%), Rp. 1,000,000 to Rp. 3,000,000 (37\%), Rp. 3,000,001 - Rp. 5,000,000 (7\%) while $15 \%$ did not respond.

Based on these data it can be understood that FUAD alumni have high absorption because most of their alumni can be quickly absorbed by the world of work in accordance with their fields and rankings, both at the local, national and international levels. Furthermore, it can also be seen that after alumni work, they are gradually able to increase their income, as evidenced in the data of an increase in the amount of salary received when they first worked with their last salary. It also means that the rewards received by alumni increase as their working years increase. Therefore, it can also be concluded 
that the existence of FUAD IAIN Pekalongan has relevance to the world of work.

The implementation and quality of service here is related to aspects of learning, aspects of teaching and learning, the condition of learning facilities, the contribution of tertiary institutions to competence and foreign languages and the benefits of majors for alumni. First, in the learning aspect, the evaluation points include an emphasis on six aspects, namely lectures, demonstrations or experiment, participation in research projects, internships, field work practicum and discussions. FUAD Alumni considered that in general learning at FUAD IAIN Pekalongan was very good. Lectures and discussions received very good ratings, meaning according to the alumni both aspects were given a very big emphasis from the Faculty. But in the aspect of demonstration or experiment they considered less. Such information can be used as an evaluation of the Faculty that the Faculty has given good lectures to its students, so it must be maintained and improved. Demonstration or experiment activities also need to be emphasized more on students. Demonstration or experiment activities are alternative solutions in learning (Billah, 2016); discussion and demonstration method considered as the contribution to the graduate students (Muchsin \& Hasbahuddin, 2018).

Second, in the aspect of teaching and learning, the assessment points on 5 (five) things, namely the opportunity to interact with lecturers outside the lecture schedule, academic guidance, the opportunity to participate in research projects, the general conditions of teaching and learning, the opportunity to enter and become part of a network of professional scientists. FUAD alumni generally rated the five aspects as being well implemented, but they considered that they lacked the opportunity to enter and become part of the professional 
scientific network. This certainly can be input for the Faculty to provide broad opportunities for students to develop professional scientific networks so that they can have adequate provisions before entering the workforce.

Third, aspects of the condition of learning facilities assessed are supporting facilities for lectures including: libraries, information and communication technology, learning modules, study rooms, laboratories, variety of courses offered, accommodation, canteens, student activity centers and facilities, mosques and health services. The facility that gets the best rating is the library. While the lowest are health services, laboratories and canteens. This information can be input for the faculties and institutions to always provide convenient and adequate facilities.

Fourth is the contribution of tertiary institutions to competence. Alumni considered that the contribution of tertiary institutions was already large towards all aspects of competence. This is marked by the acquisition of results in all aspects dominated by the answer "very good" contribution. While contributions to computer skills, the internet and the ability to write reports, memos and documents are considered to be lacking. This information can be input for the Faculty to emphasize and improve student competencies in the field of computer skills, the internet and the ability to write reports, memos and documents. Computer training activities and writing scientific reports need to be held.

The fifth is the aspect of communication ability that is closely related to the ability of foreign languages used by alumni. In this tracer study, the level of foreign language skills possessed by alumni was also measured, and how much the university contributed to the development of foreign language skills. as mentioned in the previous section that basically the contribution of tertiary 
institutions in mastering foreign languages is already large but the alumni foreign language skills are not all in the good category. As many as $43 \%$ are good, $39 \%$ are fair, and $15 \%$ say they are less able to communicate with foreign languages. This information is useful for the Faculty to further enhance activities that can hone students' language skills. Higher education deserves to consider the language skills of its graduates (Bakhtiar \& Latif, 2017).

The sixth is about the benefits of the majors for alumni. Although the alumni have finished their studies, the relationship between alumni and the Department has been established for a long time, of course there is usefulness as long as the relationship is established. The aspects that are assessed are related to the benefits of the Department in starting work, further learning in work, performance in carrying out tasks, future careers, self-development, improving entrepreneurial skills. The result was that alumni generally considered that the Department provided good benefits to alumni in all aspects. But if you look at the lowest aspect that is considered less get the role of the Department is on improving entrepreneurial skills. This information can be used as input for the Faculties so that in the future the faculties are better able to increase the provision of entrepreneurial skills to their students so that when alumni enter the workforce the alumni can expand their participation not only in the acquisition of jobs but also in the ability to open up jobs for others.

Alumni user assessment here is related to alumni performance which includes: integrity, expertise based on the field of science (professionalism), English, the use of information technology, communication, teamwork and self-development ability. As stated in the previous section, in general the ability of alumni according to the assessment of alumni users is in the good category, 
but on English language skills, 7\% of users stated less. This is in line with the alumni's own evaluation of their foreign language competencies. Most of the alumni rated that they were not able to speak foreign languages well.

In addition to the importance of increasing foreign language skills in students, alumni users also provide feedback on what skills are important to be provided to alumni, namely: information and communication technology, computers, public speaking \& public relations, pedagogical competence for teachers, leadership, work skills same with teams and individuals. Alumni users also provide advice in efforts to strengthen alumni competencies as follows: increasing capabilities in the field of information and communication technology and computer skills, increasing religious insight and implementation in the community, optimizing the job training activities so that alumni truly have sufficient stock to enter the world of work, improvement of students' soft skills to be able to develop themselves in the field of entrepreneurship.

Various information on the results of this tracer study as one form of self-evaluation from internal aspects is used as material for consideration or input for improving the quality of higher education. Various strategic steps must continue to be done in an effort to improve students' skills and competencies. This must be done to support the birth of alumni who have spiritual intelligence, breadth of knowledge, loyalty to Indonesia, and independence in life as stated in the Institute's goals so that the vision and mission of IAIN Pekalongan can be achieved. 


\section{CONCLUSION}

Based on the results of research and discussion that has been presented in the previous section, it can be concluded that:

1. Alumni Profile of the FUAD IAIN Pekalongan who graduated in 20132016 has high absorption ability. This is evidenced by the data obtained that $47 \%$ of the number of respondents in working positions, $21 \%$ are entrepreneurs, $16 \%$ are employed and self-employed and $16 \%$ are not working/continuing their studies. Only $16 \%$ of alumni are in a position not working, either for reasons of continuing their studies, having a family, or others;

2. Alumni assess the implementation and quality of service is good from all aspects, but it needs improvement from the aspect of facilities and infrastructure facilities; and

3. Alumni users rated the performance of FUAD IAIN Pekalongan alumni in the good category. The alumni competence in terms of aspects of integrity, professionalism, use of information technology, communication, teamwork, and self-development are good, but still need improvement in the use of English.

\section{REFERENCES}

Arwani, A. (2015). Kontribusi Lulusan Program Studi D3 Perbankan Syariah dan Ekonomi Syariah STAIN Pekalongan terhadap Kebutuhan Sumber Daya Insani (SDI) pada Lembaga Keuangan Syariah di Pekalongan dan Batang.

Bakhtiar, M. I., \& Latif, S. (2017). Tracer Study Alumni: Upaya Pengembangan Prodi Bimbingan Konseling Universitas Negeri Makassar. Jurnal Kajian Bimbingan Dan Konseling, 2(1), 32-40. 
Billah, A. (2016). Pendidikan Karakter Untuk Anak Usia Dini dalam Perspektif Islam dan Implementasinya dalam Materi Sains. ATTARBIYAH: Journal of Islamic Culture and Education, 1(2), 243-272.

Budi, B. S., \& Dinan, A. (2017). Report Tracer Study ITB 2015. Bandung: ITB Press.

Ditjen Belmawa. (2016). Buku Panduan Pusat Karir. Kementerian Riset Teknologi dan Pendidikan Tinggi Republik Indonesia.

Finch, C. R., \& Crunkilton, J. R. (1979). Curriculum Development in Vocational and Technical Education: Planning Content and Implementation. USA: Allyn $\&$ Bacon.

Halasz, I., \& Behm, K. (1982). Evaluating Vocational Education Programs, A Handbook for Corrections Educators. In Research and Development Series No. 227 (p. 9). Ohio: National Center for Research in Vocational Education, Ohio State University.

Hermanto, T., Furqan, M., \& Hasyim, F. (2015). Sistem Informasi Administrasi Tracer Study dan Kepuasan Stakeholders Alumni STT Nurul Jadid Berbasis Web. Jurnal Teknik Informatika, 7(1), 49-63.

ITB. (2014). Buku Report Tracer Study ITB. Bandung.

Muchsin, S. B., \& Hasbahuddin. (2018). Studi Pelacakan Alumni Keguruan STKIP Andi Matappa. Jurnal Konseling Andi Matappa, 2(1), 26-32.

Nurchamid, S. (2017). Kontribusi Alumni Tarbiyah dalam Pengembangan Bidang Akademik dan Nonakademik untuk STAIN Pekalongan tahun 2011-2016. IAIN Pekalongan.

Rahim, M. (2017). Tracer Study Lulusan Program Studi Bimbingan dan Konseling Universitas Gorontalo. Jurnal Pendidikan (Teori Dan Praktik), 2(2), 121-127.

Schomburg, H. (2003). Handbook for Graduate Tracer Studies (3rd ed.). Kassel, Germany: Centre for Research on Higher Education and Work University of Kassel.

Setemen, K. (2009). Pelacakan Alumni (Tracer Study) Jurusan Manajemen Informatika Berbasis ICT (Information \& Communication Technology). JPTK, UNDIKSHA, 6(2), 13-26.

Soesilo, T. D., \& Setyorini. (2005). Kinerja Alumni BK FISIP UKSW dan 
Faktor yang Melatarbelakangi. Satya Widya, 18(1).

Suharti, L. (2012). Studi Penelusuran (Tracer Study) terhadap Alumni Program Studi Manajemen Fakultas Ekonomika dan Bisnis Universitas Kristen Satya Wacana. In PEKAN ILMIAH DOSEN FEB-UKSW (pp. 231-248).

Sukardi, T. (2011). Studi Penelusuran Lulusan S1 Kependidikan fakultas Teknik Universitas Negeri Yogyakarta. Jurnal Pendidikan Teknologi Dan Kejuruan, 20(2), 196-202.

Suryani, K., Khairudin, \& Syahmaidi, E. (2017). Online Tracer Study of Bung Hatta University. International Journal of GEOMATE, 13(37), 20-27.

Syam, A., \& Manga, A. R. (2017). Sistem Tracer Study Alumni Fakultas Ilmu Komputer Universitas Muslim Indonesia Menggunakan Metode On-Line Analitycal Processing (OLAP). ILKOM Jurnal Ilmiah, 9(1), 86-90.

Yani, D. E., Pertiwi, P. R., Fadila, I., Puspitasari, K. A., \& Huda, N. (2012). Tracer Study pada Program Studi S1 Agribisnis FMIPA-Universitas Terbuka. Jurnal Pendidikan Terbuka dan Jarak Jauh, 13(2), 94-105. 